\section{Functional T Lymphocyte Immune Deficiency in a Population of Homosexual Men Who Do Not Exhibit Symptoms of Acquired Immune Deficiency Syndrome}

Gene M. Shearer, Susan M. Payne, Loren J. Joseph, and William E. Biddison

Immunology Branch, National Cancer Institute, and Neuroimmunology Branch, National Institutes of Neurological and Communicative Disorders and Stroke, National Institutes of Health, Bethesda, Maryland 20205 bstract. To determine whether healthy homosexual men are immunologically impaired, peripheral blood leukocytes (PBL) from 20 male homosexuals were compared prospectively with PBL from 14 age-matched male heterosexual donors with respect to: $(a)$ the capacity of their PBL to generate functional $T$ cell immune responses in vitro; and $(b)$ the content of total $\mathrm{T}$ cells and $T$ cell subsets in their peripheral blood. The homosexual donors studied indicated moderate sexual life styles in that all but one of the donors had less than five current sexual partners. The percentages of $\mathrm{OKT}^{+}, \mathrm{OKT}^{+}$, and $\mathrm{OKT}^{+} \mathrm{T}$ cells were similar to those of heterosexual controls. $T$ cell function was assessed by measuring cytotoxic $T$ cell responses to influenza virus and to allogeneic cells. Approximately one-third of the homosexual donors consistently exhibited weak cytotoxic T lymphocyte (CTL) responses to influenza virus, whereas all of the heterosexual donors generated strong CTL responses to influenza. There was no correlation between the strength of CTL responsiveness to influenza virus and the strength of CTL responses to allogeneic cells. These results suggest that the influenza-specific CTL response may be a sensitive indicator of immunologic defects in asymptomatic homosexuals. If acquired immune deficiency syndrome results from an infectious agent, it remains to be seen if such immunosuppression predisposes to the infection, or if it reflects early consequences of infection.

Received for publication 2 December 1983 and in revised form 10 April 1984.

The Journal of Clinical Investigation, Inc.

Volume 74, August 1984, 496-506

\section{Introduction}

The acquired immunodeficiency syndrome (AIDS) ${ }^{1}$ was first recognized $2 \frac{1}{2}$ years ago as a distinct entity characterized by the appearance of opportunistic infections and/or Kaposi's sarcoma in previously healthy homosexual men, thus strongly indicating the presence of an unexplained acquired immunodeficiency (1-3). Subsequently, a number of populations have been identified as being at high risk for AIDS, including homosexual men (4-8), intravenous drug users (6-10), Haitians (11-12), hemophiliac recipients of Factor VIII concentrates (13-15), recipients of multiple blood transfusions $(16,17)$, sexual contacts of AIDS patients, and possibly infant children of AIDS patients (18-20). Despite intensive clinical and research efforts, a number of major problems remain unresolved, including identification of the etiologic agent(s), early diagnosis, and the development of an effective therapeutic protocol. The etiologic candidate favored by many investigators working with AIDS is a new infectious agent (21), possibly a variant $T$ lymphocytotropic virus (22-25). Nevertheless, since the immunological abnormalities associated with AIDS are complex, it has been postulated that the syndrome is multifactorial and that cofactors of an infectious or noninfectious nature could either contribute to the induction of AIDS or to susceptibility to the AIDS agent(s) by reducing immune potential (26-29). If such cofactors contribute to the syndrome, it might be possible to demonstrate functional immune abnormalities among individuals who are at risk for AIDS, but who do not exhibit identifiable AIDS symptoms. Alternatively, preclinical immunologic defects may be found even if there are no such cofactor requirements. Pre-

1. Abbreviations used in this paper: AIDS, acquired immune deficiency syndrome; CMV, cytomegalovirus; CTL, cytotoxic T lymphocyte; EBV, Epstein-Barr virus; FMF, flow microfluorometry; PBL, peripheral blood leukocytes; PHA, phytohemagglutinin. 
vious reports have demonstrated defects in polyclonal proliferative responses to mitogens and delayed skin reactions in homosexual men and in hemophiliac recipients of Factor VIII concentrates who present with other findings such as helper/ suppressor $\mathrm{T}$ cell ratio reversals and/or lymphadenopathy (8, 30-34).

In the present study, the following hypothesis was considered: homosexual men with less promiscuous life-styles than most homosexual AIDS patients could nevertheless be immune-compromised, possibly as a result of their sexual practices. If this were the case, analysis of specific immunologic functions of these individuals might detect subtle defects that could not be detected by mitogen-stimulated proliferative responses or by helper/suppressor cell analysis. Therefore, a study of this type might identify particular immune defects in individuals before the onset of AIDS-related symptoms. The ability of peripheral blood leukocytes (PBL) to generate in vitro cytotoxic $T$ lymphocyte (CTL) responses to influenza virus (35-39) was chosen as an example of specific $\mathrm{T}$ lymphocyte immune function because the antiinfluenza CTL response has been investigated in more than 150 normal volunteers over a 5-yr period (35-39). Furthermore, influenza viruses are known to be recognized by CTL in association with class I HLA self-antigens (35-38), except perhaps for HLA B40 (37). No HLA haplotype has been identified in which the donor is a genetic nonresponder (38). The CTL response is both helper T lymphocyte- and accessory celldependent (39), which indicates that complex cellular interactions that involve a variety of elements are required to generate a CTL response to this virus. The data indicate that the ability to generate in vitro responses to influenza virus is defective in certain individuals among a population of homosexual men who do not exhibit AIDS-related symptoms nor abnormal numbers of $\mathrm{OKT} 4^{+}$and $\mathrm{OKT} 8^{+}$cells. The demonstration of a particular immune dysfunction among individuals from a highrisk group who do not otherwise appear to be at risk are discussed with respect to the possible early detection of AIDS-related functional immune abnormalities in the absence of OKT4/ OKT8 reversals and the identification in a high-risk group of apparently healthy individuals who might be immune deficient.

\section{Methods}

Blood donors. Homosexual men from the Washington, DC area were recruited on a volunteer basis (experimental group). Heterosexual men of the same age range were recruited as controls from laboratory personnel at the National Institutes of Health (NIH) (control group). Each donor from the experimental and control groups was assigned a number and was subsequently identified in all experiments by this number. Within each experiment, the responses of one or two homosexuals were compared with those of one or two heterosexuals. One pair of homosexual partners was compared (donors 5 and 8). At the time of this report, each donor has had functional studies performed at least twice during a period from 3 to $18 \mathrm{mo}$; and, in some cases, up to six independent functional tests have been performed.

Phlebotomy. In each experiment, $100 \mathrm{~cm}^{3}$ of whole blood was drawn sterilely from each donor by venopuncture into $60-\mathrm{cm}^{3}$ syringes that contained 1,000 U of perservative-free heparin (PANHEPARIN, Abbott Laboratories, North Chicago, IL). PBL were separated on Ficoll-Hypaque $(35,36)$ and were used in a variety of immunological tests (see below). In some cases aliquots of cells were cryopreserved under controlled freezing-rate conditions, and the frozen cells were stored in liquid nitrogen for later studies $(35,36)$. Sera were also collected and frozen at $-70^{\circ} \mathrm{C}$ for hepatitis B antigen testing, and for antibody titers to hepatitis B, Epstein-Barr virus (EBV), cytomegalovirus (CMV), and influenza virus.

Generation of in vitro CTL responses. CTL responses to influenza A/Bangkok/RX73 (H3N2) (RX73) and alloantigens were generated in 24-well plates (Linbro, Flow Laboratories, Inc., McLean, VA) in medium that consisted of RPMI 1640 with glutamine (Gibco Laboratories, Grand Island, NY) supplemented with $100 \mathrm{U} / \mathrm{ml}$ penicillin, $100 \mu \mathrm{g} / \mathrm{ml}$ streptomycin, and 5\% normal human heparinized plasma (complete medium) $(35,36)$. RX73 virus was used as infectious allantoic fluid (256-512 hemagglutination $\mathrm{U} / \mathrm{ml}$ ) obtained from inoculated hens' eggs. Anti-RX73 CTL responses were generated by culturing $3-4 \times 10^{6} \mathrm{PBL}$ in $2 \mathrm{ml}$ of a 1:2,000 dilution of RX73 in RPMI 1640 for $1 \mathrm{~h}$ at $37^{\circ} \mathrm{C}$. One-tenth milliliter of plasma was then added to each well to yield a final concentration of $5 \%$. The plates were incubated for $7 \mathrm{~d}$ at $37^{\circ} \mathrm{C}$ in a humidified atmosphere of $5 \% \mathrm{CO}_{2}$ in air.

Allogeneic CTL responses were generated by culturing $3 \times 10^{6}$ responder PBL and $1 \times 10^{6} 2,000$ Rad-irradiated $\left({ }^{137} \mathrm{Cs}\right.$ source, Isomedix, Inc., Parsippany, NJ) stimulator PBL in $2 \mathrm{ml}$ of complete medium for $7 \mathrm{~d}$, as above.

${ }^{5 I} \mathrm{Cr}$ Release assay for $C T L$. Influenza-immune PBL were assayed on autologous-infected targets and alloimmune CTL were assayed on uninfected targets identical to the allostimulator cells. Phytohemagglutinin (PHA)-stimulated PBL were used as targets for both anti-RX73 and antiallogeneic CTL. PHA stimulation was performed by culturing 10-12 $\times 10^{6} \mathrm{PBL}$ in upright flasks (Falcon No. 3013, Becton-Dickinson \& Co., Oxnard, CA) in $8 \mathrm{ml}$ of complete medium for $4 \mathrm{~d}$ at $37^{\circ} \mathrm{C}$ and then adding $1 \mathrm{ml}$ of a 1:20 dilution of PHA (M Form, Gibco Laboratories) and culturing for another $3 \mathrm{~d}$. PHA-stimulated PBL were harvested and resuspended in $0.7 \mathrm{ml}$ assay medium (RPMI 1640 with glutamine and antibiotics further supplemented with nonessential amino acids and $5 \%$ heat-inactivated fetal calf serum) plus $250 \mu \mathrm{Ci} \mathrm{Na}{ }_{2}^{51} \mathrm{CrO}_{4}$ (New England Nuclear, Boston, MA). For influenza-infected targets, $0.1 \mathrm{ml}$ of infectious allantoic fluid was added. Targets were incubated for $90 \mathrm{~min}$, washed once, and cultured for $4 \mathrm{~h}$ at $37^{\circ} \mathrm{C}(35,36)$. Targets were then washed once more and diluted to $1 \times 10^{5} / \mathrm{ml}$. Effector cells $(0.1 \mathrm{ml})$ and a constant number of targets $\left(10^{4} \mathrm{in} 0.1 \mathrm{ml}\right)$ were added in varying ratios to round-bottomed microtiter plate wells (Linbro, Flow Laboratories, Inc.), the plates were centrifuged for $2 \mathrm{~min}$ at $10 \mathrm{~g}$ and incubated for $6 \mathrm{~h}$ at $37^{\circ} \mathrm{C}$. The plates were centrifuged for $5 \mathrm{~min}$ at $250 \mathrm{~g}$. The supernatants were harvested, and gamma emissions were counted to measure ${ }^{51} \mathrm{Cr}$ release. Results are expressed as percent lysis and are calculated by the following formula: (experimental release - spontaneous release)/(maximal release - spontaneous release) $\times 100$, as previously described $(35,36)$. Standard errors of the mean have been excluded from the data presented here since they were consistently $<10 \%$.

Serum antibody tests. Hepatitis B antigen and antibody tests were performed by the NIH Blood Bank. Serum antibody titers to CMV were determined by an indirect immunofluorescence assay (40). Antibody titers to the viral capsid antigens of EBV were determined by an indirect fluorescent-antibody assay (41). Serum antiinfluenza A/Bangkok (H3N2) (the same virus used for the CTL testing) antibody titers were assayed by the enzyme-linked immunoassay described previously (42). 
Analysis of OKT antigen expression. Donor PBL were analyzed for surface expression of OKT3, OKT4, and OKT8 (Ortho Pharmaceuticals, Raritan, NJ) by using indirect immunofluorescence by flow microfluorometry (FMF). All dilutions and washes were performed in Hanks' buffered saline solution without phenol red (Gibco Laboratories, No. $310-4025$ ) containing $0.25 \%$ human serum albumin and $0.1 \% \mathrm{NaN}_{3}$. $1-2 \times 10^{6}$ cells were incubated in $150 \mu \mathrm{l}$ of ascites antibody (generously provided by Dr. G. Goldstein, Ortho Pharmaceuticals) diluted $1: 10^{3}$ for $30 \mathrm{~min}$ at $4^{\circ} \mathrm{C}$. After incubation, cells were washed twice and incubated in a 1:5 dilution of fluorescein-conjugated $F(a b)^{\prime 2} 2$ fragment of rabbit anti-mouse IgG (heavy and light chains) (Cappel Laboratories, Cochranville, PA) for 30 min at $4^{\circ} \mathrm{C}$. After two washes to remove unbound fluoresceinated antibody, cells were incubated in $0.5 \mathrm{ml}$ fixative $(2.5 \%$ paraformaldehyde and $0.125 \mathrm{M}$ cacadylic acid in aqueous solution) as a precaution for $15 \mathrm{~min}$ at room temperature. After fixation, the cells were washed twice and were then analyzed by FMF with an FACS II (Becton-Dickinson \& Co.) as previously described (39).

\section{Results}

$C T L$ responses. $\mathrm{PBL}$ were sensitized in vitro to influenza virus or HLA alloantigens, and the CTL activity that was generated after $7 \mathrm{~d}$ of culture was assayed on ${ }^{51} \mathrm{Cr}$-labeled PHA blasts. Uninfected and influenza-infected autologous PHA blasts were used to assay the antiinfluenza CTL responses; and uninfected allogeneic PHA blasts were used to assay for the antialloantigen CTL responses. To date, $>70$ independent experiments were performed that compared the CTL responses of experimental and control donors. 15 representative experiments are shown in Fig. 1 in which the antiinfluenza responses of one or two homosexual donors were compared with those of one or two control donors. PBL from all control donors generated strong antiinfluenza CTL activity. PBL from some homosexual donors generated CTL responses similar in magnitude (experiments 35 , 38,43 [donor 3], and 47), and in some cases slightly higher (experiments 44, 46, and 50 [donor 11]) than the responses of control donors. CTL responses generated from other homosexual donors, however, were very weak (experiments 36, 39, 43 [donor 2], and 45 [donor 10]). In some experiments, the responses of homosexual donors were moderately weak when compared with heterosexual controls (experiments 37, 40, 49, and 52). We occasionally observed experiments in which one homosexual donor was a strong responder, whereas the other was a weak responder (experiments 43 and 45). It should also be noted that donor 10 was a low antiinfluenza CTL responder when bled and at two different times studied (experiments 39 and 45).

The latter comparison raises a relevant point in a study of this type, i.e., whether donors bled or tested for immune function at different time intervals will exhibit similar response patterns. The results summarized in Fig. 2 show representative antiinfluenza CTL responses of PBL drawn from repetitive tests of some of the donors shown in Fig. 1. The time intervals for repetitive bleeding and testing ranged from 1 to $5 \mathrm{mo}$. The results indicate that irrespective of time of the test, the experimental and control donors exhibited a consistent response pattern during this interval of study. Thus, homosexual donors that responded weakly in one experiment were also weak responders in subsequent, independent tests. Homosexual donors

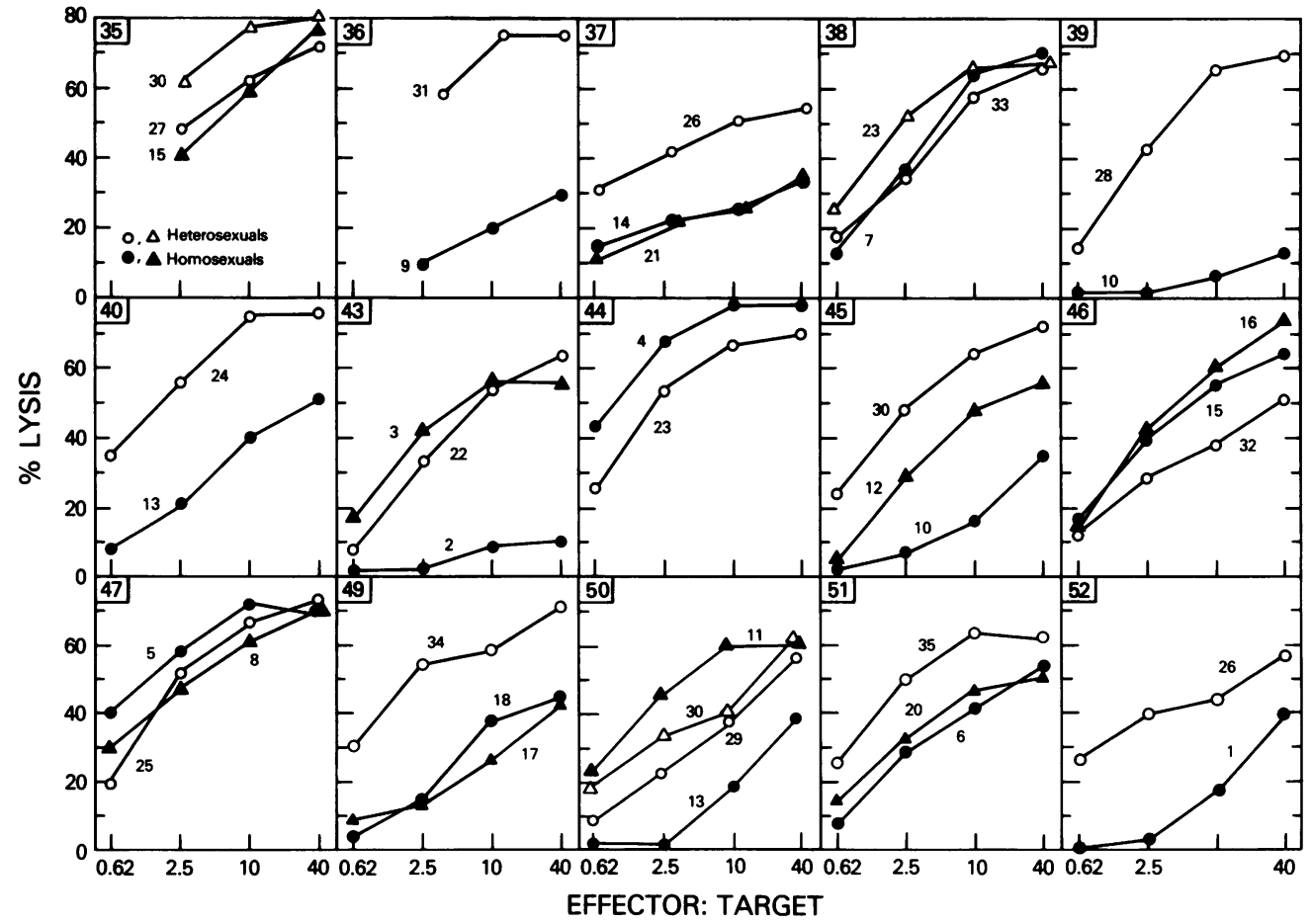

Figure 1. Cytotoxic T lymphocyte responses of 21 homosexual and 14 heterosexual donors to influenza virus-infected autologous leukocytes. 15 separate representative experiments are summarized in which effector/target cell ratio is plotted as a function of percent lysis. Numbers in the inserts indicate experiment numbers; numbers associated with data indicate donor identification numbers. Data from unsensitized cultures from each donor have been omitted since they were consistently $<10 \%$. 


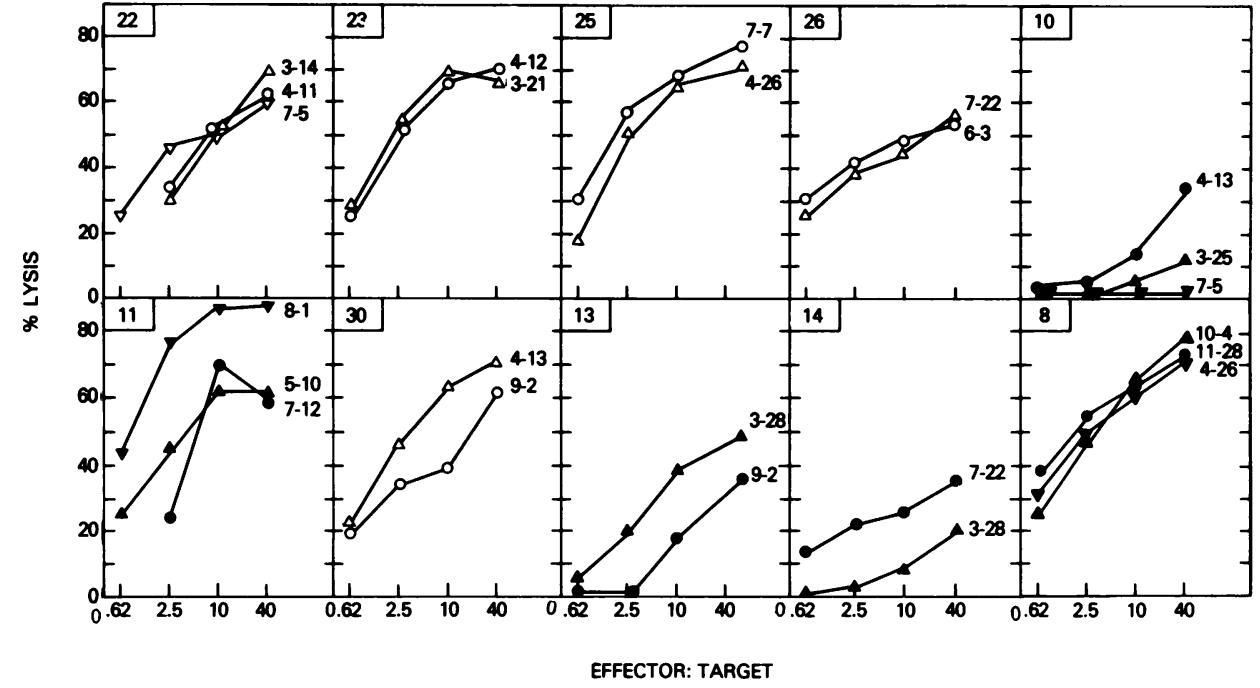

Figure 2. Repetitive cytotoxic T lymphocyte responses of homosexual $(\bullet, \Delta, \nabla)$ and heterosexual $(0$, $\Delta, \nabla)$ donors. Numbers in the inserts indicate donor identification numbers. Dates (in 1983) of the repetitive CTL tests are shown next to the data curves. that were strong responders in one test were also strong responders in a second, independent test. We have not yet observed any homosexuals who converted from a high responder to a low responder status during the first $18 \mathrm{mo}$ of this study. For some donors, independent tests were performed three or more times (e.g., donors 10 and 11, Fig. 2). All heterosexual donors were strong CTL responders to influenza in repetitive tests. It should be noted that homosexual donors were compared with different heterosexual control donors in most of the repetitive tests. Due to the fact that the absolute levels of lysis for any one heterosexual control can vary from one experiment to another, the most meaningful comparisons are those in which the CTL responses of heterosexuals and homosexuals are compared within one experiment rather than between experiments.

The data of the individual experiments shown in Fig. 1 were also pooled and are plotted in Fig. 3 at the three highest effector/ target cell ratios for comparison among, as well as within, experiments. The mean lysis values of the heterosexual control group were consistently greater than those of the homosexual experimental group. The mean values at effector/target ratios of $40: 1,10: 1$, and $2.5: 1$ were, respectively, $66.6,59.1$, and $43.4 \%$ for heterosexuals and $47.0,42.3$, and $26.5 \%$ for homosexuals. The variance of the homosexual groups was considerably greater than that of the heterosexual group, which indicates a broader range of responses. If the CTL responses of homosexuals that fall two standard deviations below the mean of the heterosexual group are considered to be weak responders, then eight of 20 homosexual donors can be classified as weak responders, i.e., donors $1,2,9,10,14,17,18,20$. The $P$ value by Fisher's exact test is statistically significant at $P=0.007$ (for a one-tailed analysis, testing the hypothesis that homosexual donors would be either weak or normal antiinfluenza responders). Even if a more conservative comparison of three standard deviations is taken as the cut-off point, five of 20 homosexual donors can be classified as weak antiinfluenza CTL responders (i.e., donors
$1,2,9,10,14)$. The $P$ value by Fisher's exact test is statistically significant at $P=0.06$.

The possibility exists that the weak CTL responses of homosexual donors was due to an inability of virus-infected target cells to be lysed by HLA-restricted, influenza-specific effectors, rather than being due to one or more functional cell types necessary for the generation of the response (e.g., helper or cytotoxic precursor cells or antigen-presenting cells). To test this possibility, CTL responses were generated by PBL from heterosexual donors

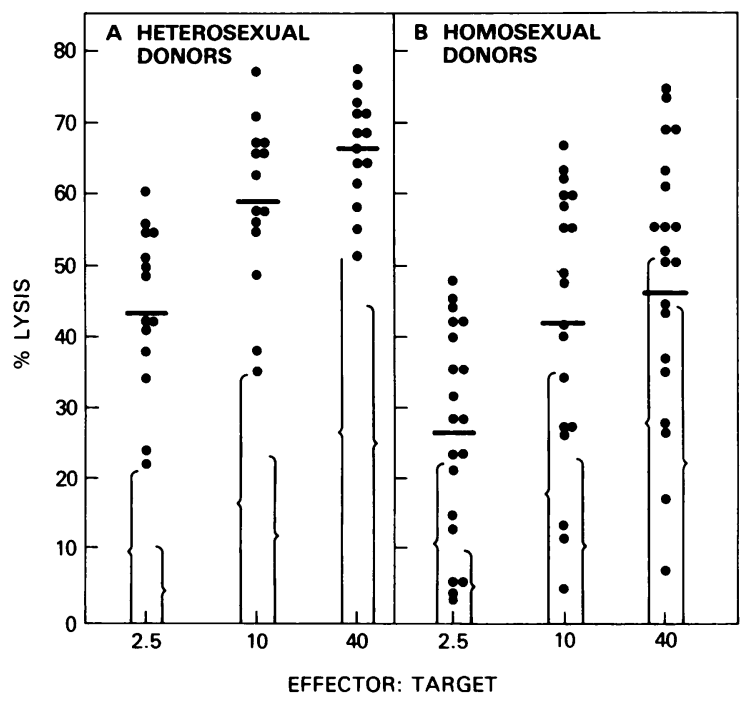

Figure 3. Pooled cytotoxic T lymphocyte responses to influenza virus of the donors shown in Fig. 1. Bars indicate the means of the percent lysis of 21 homosexual $(B)$ and 14 heterosexual $(A)$ donors at three effector/target cell ratios. Left brackets indicate two standard deviations below heterosexual means. Right brackets indicate three standard deviations below heterosexual means. 


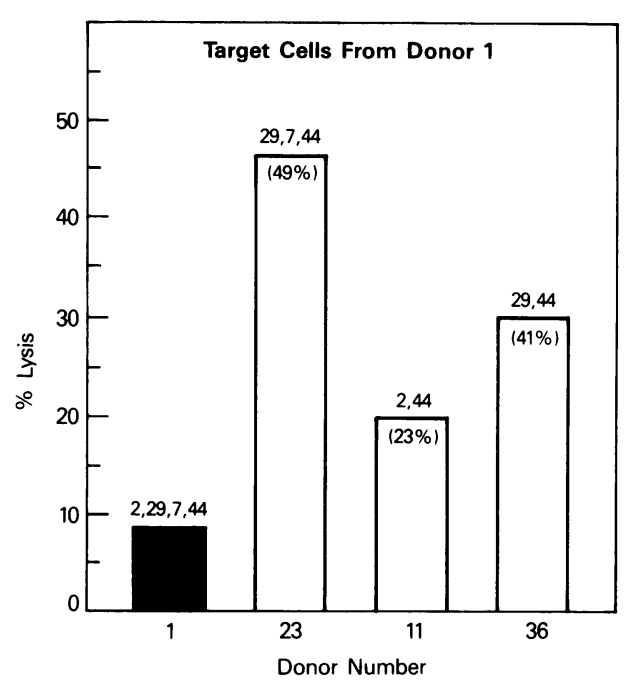

Figure 4. Influenza-specific, HLA-restricted cytotoxic T lymphocyte activity of PBL; from homosexual donors on infected autologous targets (closed bars); and from heterosexual donors or infected, partially HLA-matched targets from the homosexual donors (open bars). The (\%) indicates the CTL activity of PBL from heterosexual donors on infected autologous targets. Effector/target shown is 40:1.

and assayed on virus-infected autologous targets as well as on infected (and uninfected control) targets from weak responder homosexual donors that were partially matched with the responding and stimulating cells at HLA-A and HLA-B loci. The results, summarized in Fig. 4, indicate that virus-infected target cells from a weak responder homosexual donor were efficiently lysed by effectors from strong responder donors. For example, effector cells from heterosexual donor 23 , which were matched for three HLA-A and HLA-B antigens (A29; B7, B44), gave $47 \%$ lysis on infected targets from homosexual weak responder donor 1, compared with $49 \%$ lysis on infected autologous targets. Similarly, only effector cells generated from homosexual donor 11 lysed infected targets from donor 1 (which was HLA-matched at $\mathrm{A} 2$ and B44 with the effector cell donor) by $20 \%$ and infected autologous targets by $23 \%$. Effectors from heterosexual donor 36 lysed infected targets from donor 1 by $30 \%$ (HLA-matched at A29, B44) and infected autologous targets by $41 \%$. Similar results were obtained in two other experiments (data not shown).

The PBL from each were also tested for their ability to generate in vitro CTL responses to HLA alloantigens. The data summarized in Table I represent examples in which the responses of homosexual donors were equal to (experiment 36 ), or weaker than (experiment 49), those of the heterosexual controls. A weakresponder status for influenza virus was not necessarily reflected in the response to HLA alloantigens.

Analysis of $T$ lymphocyte subpopulations. Helper/suppressor $T$ cell ratio reversals have been observed in AIDS patients $(1-3,8)$, as well as in healthy homosexual men at high risk for $\operatorname{AIDS}(30,31,42)$. Recent studies have indicated that the actual number of helper and suppressor $T$ cells may be more important than their ratio (43). Therefore, we have analyzed the proportion of $\mathrm{OKT}^{+}, \mathrm{OKT}^{+}$, and $\mathrm{OKT} 8^{+} \mathrm{PBL}$ in the control and experimental groups. We present the data in terms of percentage of positive cells in Fig. 5 and in terms of OKT4/OKT8 ratio in Fig. 6. None of the homosexual donors of this study exhibited an abnormal $\mathrm{T}$ cell subset when compared with our heterosexual controls.

Clinical hematology and serum antibody data. White blood cell counts and differentials were run on 14 of the 20 homosexual donors and on 13 of the heterosexual donors at the times their PBLs were tested for CTL function. The mean values of the differentials are summarized in Table II. There were no obvious abnormalities in the differentials of the homosexual donors. Donor 13 appeared to have a high proportion of atypical lymphocytes. Two of the 20 homosexual donors $(1,18)$ were positive for hepatitis B antigen and 7 were positive for hepatitis B antibody. The sera of the homosexual and heterosexual donors were tested for antibody activity to the same Bangkok strain of influenza A virus that was used in the CTL studies (42). All donors exhibited serum antibody activity to influenza $A$, which indicated that they all had been previously exposed to this virus

Table I. Allogeneic CTL Responses of Homosexual and Heterosexual Donors

\begin{tabular}{|c|c|c|c|c|c|c|c|}
\hline \multirow{2}{*}{$\begin{array}{l}\text { Exp. } \\
\text { No. }\end{array}$} & \multirow{2}{*}{$\begin{array}{l}\text { Donor } \\
\text { No. }\end{array}$} & \multirow{2}{*}{$\begin{array}{l}\text { Sexual } \\
\text { preference }\end{array}$} & \multicolumn{2}{|l|}{ HLA-A, -B Typing } & \multicolumn{3}{|c|}{ \% Lysis at $\mathrm{E} / \mathrm{T}$} \\
\hline & & & Responder & Stimulator & $40: 1$ & $10: 1$ & $2.5: 1$ \\
\hline \multirow[t]{2}{*}{36} & 31 & Heterosexual & Not typed & A28-30, B44-58 & 23 & 11 & 3 \\
\hline & 9 & Homosexual & A22-28, B35-51 & A28-30, B44-58 & 23 & 11 & 7 \\
\hline \multirow[t]{3}{*}{49} & & Heterosexual & A $1-32, \mathrm{~B} 8-18$ & A28-30, B44-58 & 20 & 7 & 2 \\
\hline & 17 & Homosexual & A3-32, B35-62 & A28-30, B44-58 & 8 & 3 & 3 \\
\hline & 18 & Homosexual & A3-29, B14-44 & A28-30, B44-58 & 7 & 2 & 0 \\
\hline \multirow[t]{2}{*}{50} & 29 & Heterosexual & A2, B7-51 & A2-24, B35-62 & 21 & 1 & 0 \\
\hline & 11 & Homosexual & A 1-2, B44-49 & A2-24, B35-62 & 34 & 22 & 7 \\
\hline
\end{tabular}




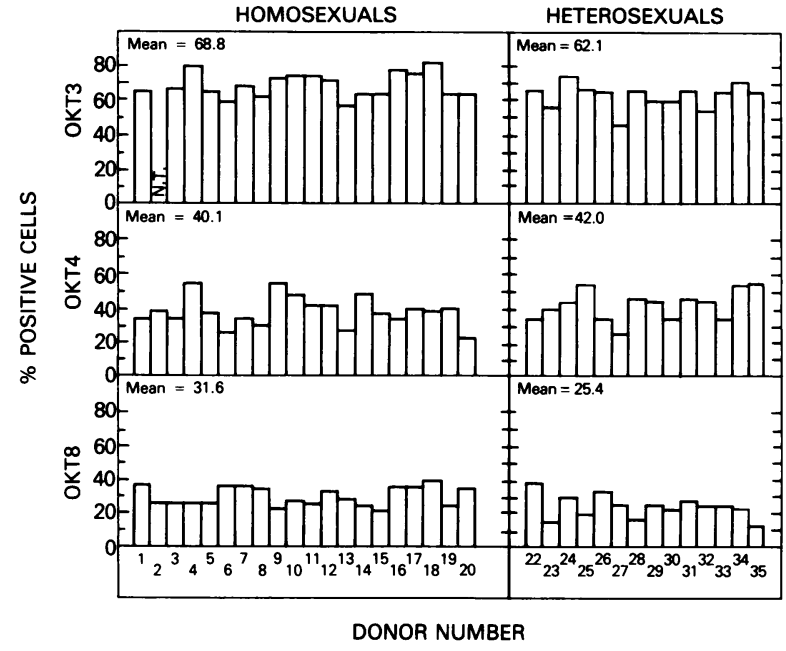

Figure 5. OKT3, OKT4, and OKT8 profiles of homosexual and heterosexual donors. Donor number is plotted as a function of the percentage of positive PBL. Mean values are shown in the panels. N.T. indicates not tested.

and that the failure to generate CTL was not due to lack of previous exposure to influenza. The mean titers were $32,000 \pm 8,100$ and $31,900 \pm 6,200 \mathrm{U}$ of antibody for the heterosexual and homosexual groups, respectively. Anti-CMV and anti-EBV antibody titers are shown in Fig. 7. Anti-CMV titers were detected in more homosexual than in heterosexual donors, whereas anti-EBV titers were more similar in the two populations. No correlation was observed between these antibody titers and CTL activity to influenza.

Life-styles of homosexual donors. To determine some aspects of the life-styles of the homosexual men who participated in this study, each homosexual donor was asked to fill out a ques-

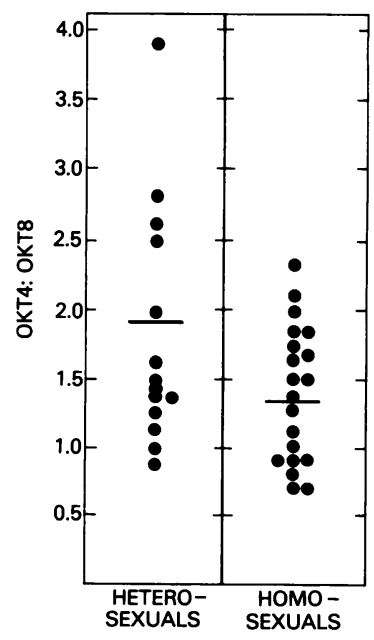

Figure 6. OKT4/OKT8 ratios for homosexual and heterosexual donors. $(\longrightarrow)$ indicates mean values for ratios. tionnaire which was concerned with medical history and life style. 15 of the 20 donors responded to the questionnaire. Potentially relevant information taken from the questionnaires is summarized in Table III. Particularly noteworthy was the observation that none of the donors would be classified as being currently promiscuous. With one exception (donor 15), none had more than four current sexual partners, although five indicated more than 100 and one more than 1,000 lifetime sexual partners. All but three donors indicated that they had reduced their number of sexual contacts and interactions since learning of AIDS. Details and current frequencies of particular homosexual practices are also shown in Table III as well as current recreational drug usage. No correlation was observed between weak anti-influenza-self CTL responses and age, number of lifetime sexual partners, or drug usage. It is also doubtful that any correlation can presently be made between weak CTL responsiveness and a particular homosexual practice. The number of homosexuals studied may be too small and the frequency of sexual interactions might be too low (i.e., donors 9,10 ) to make a strong point. However, we do not know how extensive the sexual practices of these donors might have been before the AIDS epidemic nor the possible long-term immunosuppressive effects of homosexual practices. Concerning details of the recreational drugs used, those donors who indicated that they used drugs had all used nitrate inhalants, some had used marijuana, and a few had used other drugs such as cocaine, but not heroin. No correlation was noted between drug usage and antiinfluenza CTL potential.

\section{Discussion}

A number of reports have demonstrated that AIDS patients exhibit a number of severe functional immune defects $(1-3,6$, 8) including: ( $a$ ) deficient delayed-type skin reactions to antigens in vivo (1-3); (b) an inability of PBL to proliferate when stimulated in vitro with mitogens or antigens (1-3); and $(c)$ a deficiency of helper $\mathrm{T}$ cell function for in vitro-generated immune responses (44). Other studies have shown that PBL of individuals not diagnosed as having AIDS but at high risk for the syndrome exhibit proliferative defects when stimulated with mitogens (8) and delayed-type skin reactions (32). Most of the studies of immune function in homosexual men reported so far have involved highly promiscuous subjects $(43,45)$ who had a high rate of exposure to a number of infectious agents. This research studies homosexual men with a less promiscuous and a less active sexual life and was undertaken to determine whether some of the donors would exhibit more subtle functional $T$ lymphocyte immune defects when stimulated with a specific pathogenic immunogen rather than a polyclonal activator such as a mitogen. Most of the participants in this study had from one to four current sexual partners, and the frequency of sexual interaction was considerably less than that of the AIDS highrisk homosexual men (45). 


\begin{tabular}{|c|c|c|c|c|c|c|c|c|c|}
\hline \multirow[b]{2}{*}{$\begin{array}{l}\text { Donor } \\
\text { No. }\end{array}$} & \multirow[b]{2}{*}{ WBC } & \multirow[b]{2}{*}{ PMN } & \multirow[b]{2}{*}{ Bands } & \multirow[b]{2}{*}{ Lymphocytes } & \multirow[b]{2}{*}{ Monocytes } & \multirow[b]{2}{*}{ Eosinophils } & \multirow[b]{2}{*}{$\begin{array}{l}\text { Atypical } \\
\text { lymphocytes }\end{array}$} & \multicolumn{2}{|c|}{ Hepatitis B } \\
\hline & & & & & & & & Antigen & Antibody \\
\hline \multicolumn{10}{|c|}{ Heterosexuals } \\
\hline 22 & 5,100 & 3,770 & 0 & 1,020 & 255 & 51 & & - & - \\
\hline 23 & 6,600 & 3,630 & 396 & 2,110 & 396 & 66 & & - & - \\
\hline 24 & 5,000 & 3,150 & 300 & 1,250 & 300 & 0 & & - & - \\
\hline 25 & 3,500 & 1,750 & 0 & 1,540 & 140 & 0 & & - & - \\
\hline 26 & 5,100 & 2,600 & 204 & 2,090 & 204 & 159 & & - & - \\
\hline 27 & 5,300 & 3,340 & 53 & 1,590 & 53 & 0 & & - & - \\
\hline 28 & 5,500 & 3,030 & 165 & 1,710 & 440 & 210 & & - & + \\
\hline 29 & 4,300 & 3,270 & 129 & 600 & 258 & 43 & & - & - \\
\hline 30 & 4,900 & 2,740 & 49 & 1,760 & 245 & 49 & & - & - \\
\hline 31 & 5,800 & 4,120 & 0 & 1,570 & 116 & 0 & & - & - \\
\hline 32 & 4,800 & 2,590 & 336 & 1,390 & 288 & 192 & & - & - \\
\hline 33 & 5,100 & 3,320 & 357 & 1,070 & 357 & 0 & & - & - \\
\hline 34 & 5,200 & 3,850 & 260 & 884 & 104 & 52 & & - & - \\
\hline \multicolumn{10}{|c|}{ Homosexuals } \\
\hline 1 & 4,900 & 3,280 & 294 & 1,720 & 294 & 147 & & + & - \\
\hline 2 & 4,600 & 1,980 & 0 & 4,370 & 570 & 380 & & - & - \\
\hline 3 & 5,300 & 3,450 & 0 & 1,380 & 210 & 265 & & - & + \\
\hline 4 & 5,700 & 3,360 & 114 & 1,940 & 230 & 57 & & - & - \\
\hline 5 & 8,800 & 3,870 & 176 & 3,870 & 530 & 352 & & - & - \\
\hline 7 & 4,800 & 2,350 & 336 & 1,870 & 140 & 48 & & - & + \\
\hline 8 & 13,600 & 10,100 & 272 & 2,180 & 140 & 136 & & - & - \\
\hline 9 & 6,700 & 5,090 & 67 & 1,410 & 0 & 134 & $3 \%$ & - & + \\
\hline 12 & 6,800 & 2,790 & 0 & 3,060 & 612 & 136 & $20 \%$ & - & + \\
\hline 14 & 7,200 & 3,890 & 0 & 1,150 & 648 & 0 & & - & - \\
\hline 15 & 4,400 & 1,890 & 528 & 1,140 & 616 & 220 & & - & - \\
\hline 16 & 6,500 & 1,630 & 65 & 3,510 & 455 & 390 & $6 \%$ & - & + \\
\hline 17 & 6,400 & 3,840 & 320 & 2,050 & 64 & 128 & & - & + \\
\hline 18 & 5,800 & 3,600 & 174 & 1,860 & 174 & 0 & & + & - \\
\hline
\end{tabular}

Cell numbers are expressed per cubic millimeter. WBC, white blood cells; PMN, polymorphonuclears. Heterosexuals were not tested for hepatitis $\mathbf{B}$.

We found that at least five and probably eight of 20 homosexuals in this study generated weak in vitro CTL responses to influenza virus, whereas each of the 14 heterosexual donors exhibited normal antiinfluenza CTL potential. The anti-HLA allogeneic CTL potential of the weak antiinfluenza CTL responders was weak or normal, depending on the donor studied. Reduced proliferative responses to mitogen have been reported in promiscuous homosexual donors who do not have AIDS (8). Preliminary experiments were designed to determine whether the antiinfluenza CTL response would be more sensitive than the proliferative response to mitogen for detecting immunecompromised $\mathrm{T}$ cell function. We compared the proliferative responses to PHA and the antiinfluenza CTL responses using selected donors. No differences were observed in the proliferative responses to PHA between homosexual and heterosexual donors (data not shown). The ability to generate an in vitro CTL response to influenza was chosen as a reliable indicator of $\mathrm{T}$ lymphocyte immune potential to an infectious virus for the following reasons: $(a)$ some 150 randomly selected donors had been previously tested and all were strong responders (37-39); (b) this response tests immune function to a pathogen without placing the donor at risk; $(c)$ the antiinfluenza CTL response is HLA restricted and under control of HLA-linked Ir genes $(36-38) ;(d)$ the response requires a number of interacting cells, 


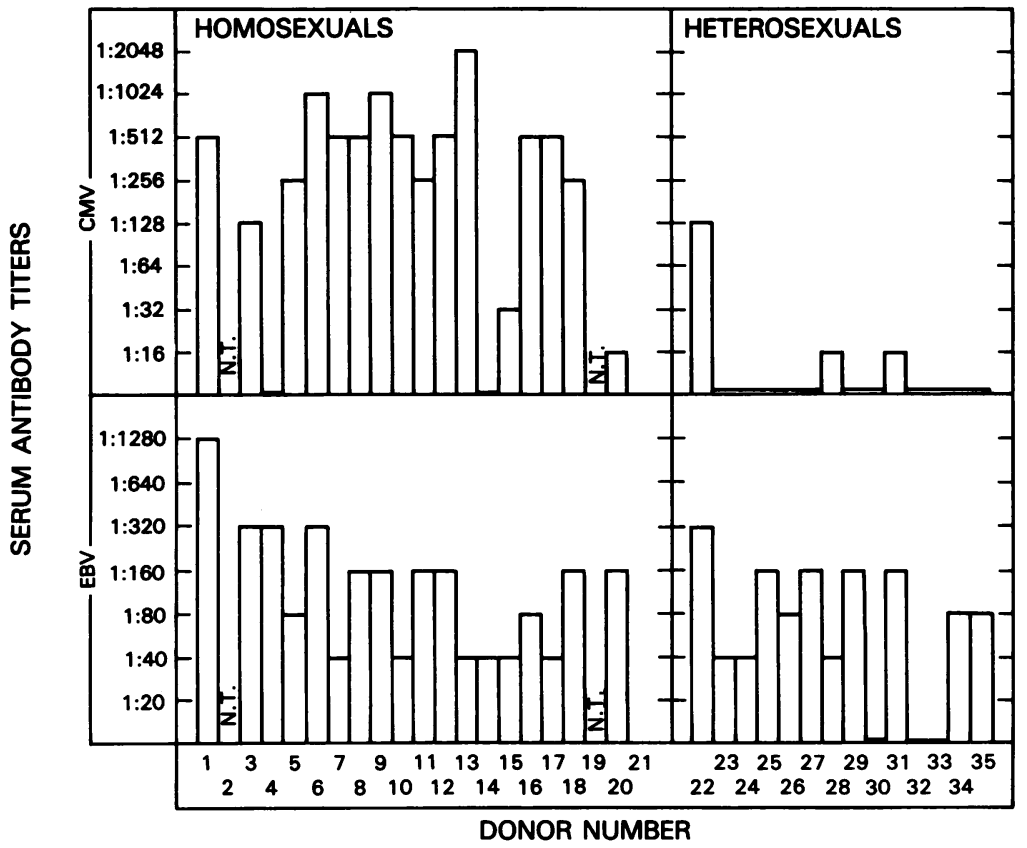

Figure 7. Serum antibody titers to CMV (upper) and to EBV (lower) in homosexual and heterosexual donors. N.T. indicates not tested. including helper cells, cytotoxic precursors, accessory cells, and target cells (39); and (e) the antiinfluenza CTL response is very dependent on helper $\mathrm{T}$ cells, whose function can be replaced by soluble helper factors (W. E. Biddison, unpublished observations).

We have demonstrated, using PBL from homosexual weak responders, that the defect in ability to generate a strong HLArestricted influenza-specific CTL response is not due to an inability of the targets to express either influenza or HLA antigens recognized by the effector cells. This indicates that the defect(s) must reside in one or more of the responding cell components. A limited kinetic comparison of CTL generated by heterosexual

Table III. Summary of Questionnaire from Homosexual Donors

\begin{tabular}{|c|c|c|c|c|c|c|c|c|}
\hline \multirow{2}{*}{$\begin{array}{l}\text { Donor } \\
\text { No. }\end{array}$} & \multirow[b]{2}{*}{ Age } & \multirow{2}{*}{$\begin{array}{l}\text { CTL response } \\
\text { to influenza }\end{array}$} & \multicolumn{2}{|c|}{ Number of sexual partners } & \multicolumn{3}{|c|}{$\begin{array}{l}\text { Frequency of current sexual practices per month } \\
\text { (active/passive) }\end{array}$} & \multirow[b]{2}{*}{ Drug use } \\
\hline & & & Lifetime & Current & Anogenital & Orogenital & Oroanal & \\
\hline 1 & 35 & Weak & $400-500$ & 1 & $1 / 1$ & $1 / 1$ & $0 / 0$ & No \\
\hline 2 & 32 & Weak & $50-100$ & 1 & $0 / 2$ & $1 / 0$ & $0 / 0$ & No \\
\hline 4 & 35 & Normal & 10-20 & 1 & $0 / 0$ & $15 / 15$ & $0 / 0$ & No \\
\hline 5 & 36 & Normal & $400-500$ & 3 & $1 / 0$ & $20 / 20$ & $6 / 3$ & Yes \\
\hline 7 & 33 & Normal & $50-100$ & 1 & $1 / 6$ & $10 / 10$ & $6 / 6$ & Yes \\
\hline 8 & 28 & Normal & $20-30$ & 3 & $1 / 0$ & $20 / 20$ & $6 / 3$ & Yes \\
\hline 9 & 36 & Weak & $100-200$ & 1 & $0.5 / 0.2$ & $1 / 1$ & $0 / 0$ & No \\
\hline 10 & 45 & Weak & 20-30 & 1 & $0.1 / 0.2$ & $0.3 / 0.3$ & $0 / 0$ & No \\
\hline 11 & 29 & Normal & $40-50$ & 2 & $12 / 10$ & $15 / 15$ & $10 / 10$ & Yes \\
\hline 12 & 26 & Normal & $100-150$ & 2 & $8 / 4$ & $8 / 8$ & $0 / 2$ & No \\
\hline 15 & 31 & Normal & $300-400$ & 25 & $3 / 0.5$ & $25 / 25$ & $3 / 3$ & Yes \\
\hline 16 & 33 & Normal & 1,500 & 3 & $4 / 0$ & $1 / 3$ & $1 / 3$ & No \\
\hline 18 & 27 & Weak & $?$ & 4 & $4 / 8$ & $16 / 16$ & $4 / 8$ & Yes \\
\hline 19 & 49 & Normal & $1-10$ & 1 & $0 / 0$ & $4 / 4$ & $0 / 0$ & No \\
\hline 20 & $?$ & Weak & $20-30$ & 2 & $4 / 4$ & $4 / 4$ & $0 / 0$ & Yes \\
\hline
\end{tabular}


strong and homosexual weak responders indicated that the heterosexual donor CTL were strong and that the homosexual CTL responses were weak on days $5,7,10$, and 14 after sensitization (data not shown). We have attempted to increase the level of influenza-specific CTL activity in PBL from low responder donors by culturing the leukocytes during sensitization with interleukin-2-containing PHA-stimulated supernatants that have been shown to support the growth of influenza-specific CTL donors. We were unable to detect any increase in CTL activity in these experiments (data not shown). It should be emphasized that the capacity to generate a response to influenza virus in vitro is simply a model to assess general immune competence, and in no way do we suggest that influenza is involved in the etiology of AIDS.

That the homosexual donors studied in this report are generally healthy and may not be at high risk for AIDS is reflected not only in their more moderate sexual activity, but also by the observations that: $(a)$ no differences were observed between the responses of homosexuals and heterosexual donors to PHA (data not shown); (b) none of the homosexual donors exhibited any evidence of helper/suppressor T cell ratio reversals; and $(c)$ the total number of these $T$ cell subpopulations were within normal limits. It should be noted that most of the donors that were weak responders to influenza have been bled and retested at least twice during the 18-mo period of this study, and all have been verified to be weak or nonresponders. All donors were typed for HLA-A, -B, -C and many of these donors were also typed for HLA-DR, -MB, -MT antigens (data not shown). There was no correlation between HLA typing and antiinfluenza CTL response. Although this CTL response is under HLA-linked Ir gene control (36-38), such regulation is reflected by preferential recognition of influenza in association with particular HLA selfdeterminants and is not detected at the level of recognition of the entire complement of self HLA determinants. On the basis of the criteria of helper and suppressor $T$ cell comparisons and details of sexual activity, the homosexual donors of the present study would not be classified as being particularly at high risk for AIDS, although they would be placed in a high-risk category due to their sexual preference. Our finding that at least onefourth of this population of donors exhibit a selective $T$ cell defect for CTL responses to influenza virus, recognized in association with self-HLA determinants, can be interpreted in one of three ways. Two opposite and extreme possibilities are that these results have nothing to do with AIDS nor with susceptibility to AIDS, or that they are indicative of a very early stage of AIDS. A third possibility, which we consider to be more likely, is that these data identify a subset of donors within a nonpromiscuous group of homosexual men whose immune systems are compromised. This in turn could make them susceptible to the AIDS infection(s).

We were unable to establish a significant correlation between weak CTL responses to influenza and particular homosexual practices. The numbers of donors are too small at present to obtain meaningful statistical values. Of the subjects tested, all donors who were weak responders had served in passive roles in anogenital sex, although donors 9 and 10 practiced anogenital sex only infrequently at the time of this study. Responses to the questionnaire provided details of current sexual practice but not details of sexual practices before the outbreak of AIDS. It is possible that the immune-compromised states of some of these homosexual donors could be attributed to a more promiscuous sexual life style before the description of AIDS.

The antiinfluenza CTL response and other immune parameters are being followed prospectively in this population of donors, as well as in homosexual men from two other areas of the United States during the next two years to determine whether any of them develop more severe immune abnormalities and/ or AIDS. In this context it should be noted that one homosexual volunteer in our study (not included in this report) exhibited: (a) no detectable CTL activity to influenza virus; (b) elevated CTL activity to HLA alloantigens; and (c) a decrease in OKT4 ${ }^{+}$ cells. This donor recently contracted Pneumocystis carinii, 10 mo after he entered our prospective study and has been tenetatively diagnosed as having AIDS.

\section{Acknowledgments}

The authors thank Mr. Paul Kriebel and Ms. Denise Bernstein for excellent and dedicated technical assistance. The authors are grateful to Ms. Susan Sharrow and Mr. David Stephany for performing flow microfluorometry, to Dr. David Nelson for performing the antiinfluenza antibody assays, to the NIH Clinical Hematology Laboratory for performing leukocyte differentials, to the NIH Blood Bank for performing hepatitis B tests, and to Drs. Anthony Fauci, David Nelson, Stephen Shaw and Robert Yarchoan for reviewing the manuscript.

\section{References}

1. Gottlieb, M. S., R. Shraff, H. M. Schanker, J. D. Weisman, P. T. Fan, R. A. Wolf, and A. Saxon. 1981. Pneumocystis carinii pneumonia and mucosal candidiasis in previously healthy homosexual men. N. Engl. J. Med. 305:1425-1430.

2. Masur, H., M. A. Michelis, J. B. Greene, I. Onoratol, R. A. Vande Stouwe, R. S. Holzman, G. Wormser, L. Brettman, M. Lange, H. W. Murray, and S. Cunningham-Rundles. 1981. An outbreak of communityacquired Pneumocystis carinii pneumonia. N. Engl. J. Med. 305:14311438.

3. Siegal, F. P., C. Lopez, G. S. Hammer, A. E. Brown, S. J. Kornfeld, J. Gold, J. Hassett, S. Z. Hirschman, C. Cunningham-Rundles, B. R. Adelsberg, D. M. Parham, M. Siegal, S. Cunningham-Rundles, and D. Armstrong. 1981. Severe acquired immunodeficiency in male homosexuals manifested by chronic perianal ulcerative Herpes simplex lesions. N. Engl. J. Med. 305:1439-1444.

4. Special Report of the Centers for Disease Control Task Force on Kaposi's Sarcoma and Opportunistic Infections. 1982. Epidemiological aspects of the current outbreak of Kaposi's sarcoma and opportunistic infections. N. Engl. J. Med. 306:248-252.

5. Friedman-Kien, A. E., L. J. Laubenstein, P. Rubinstein, E. Buimovici-Klein, M. Marmor, R. Stahl, I. Spigland, K. S. Kim, and S. 
Zolla-Pazner. 1982. Disseminated Kaposi's sarcoma in homosexual men. Ann. Intern. Med. 96:693-700.

6. Mildvan, D., U. Mathur, R. W. Enlow, P. L. Romain, R. J. Winchester, C. Cop, H. Singman, B. R. Adelsberg, and I. Spigland. 1982. Opportunistic infections and immune deficiency in homosexual men. Ann. Intern. Med. 96:700-704.

7. Follansbee, S. E., D. F. Busch, C. B. Wofsy, D. L. Coleman, J. Gullet, G. P. Aurigemma, T. Ross, W. K. Hadley, and W. L. Drew. 1982. An outbreak of Pneumocystis carinii pneumonia in homosexual men. Ann. Intern. Med. 96:705-713.

8. Stahl, R. E., A. Friedman-Kien, R. Dubin, M. Marmor, and S. Zolla-Pazner. 1982. Immunologic abnormalities in homosexual men. Relationship to Kaposi's sarcoma. Am. J. Med. 73:171-178.

9. Masur, H., M. A. Michelis, G. P. Wormser, S. Lewin, J. Gold, M. L. Tapper, J. Giron, C. W. Lerner, D. Armstrong, U. Setia, J. A. Sender, R. S. Siebken, P. Nicholas, Z. Arlen, S. Maayan, J. A. Ernst, F. P. Siegal, and S. Cunningham-Rundles. 1982. Opportunistic infection in previously healthy women. Ann. Intern. Med. 97:533-539.

10. Wormser, G. P., L. B. Krupp, J. P. Hanrahan, G. Gavis, T. J. Spira, and S. Cunningham-Rundles. 1983. Acquired immunodeficiency syndrome in male prisoners. Ann. Intern. Med. 98:297-303.

11. Pitchenik, A. E., M. A. Fischl, G. M. Dickinson, D. M. Becker, A. M. Fournier, M. T. O'Connell, R. M. Colton, and T. J. Spira. 1983. Opportunistic infections and Kaposi's sarcoma among Haitians: evidence of a new acquired immunodeficiency state. Ann. Intern. Med. 98:277284.

12. Veira, J., E. Frank, T. J. Spira, and S. H. Landesman. 1983. Acquired immune deficiency in Haitians. N. Engl. J. Med. 308:125129.

13. Poon, M., A. Landay, E. F. Prasthofer, and S. Stagno. 1983. Acquired immunodeficiency syndrome with Pneumocystis carinii pneumonia and Mycobacterium avium-intracellulare infection in a previously healthy patient with classic hemophilia. Ann. Intern. Med. 98:287-290.

14. Elliott, J. L., W. L. Hoppes, M. S. Platt, J. G. Thomas, I. P. Patel, and A. Gansar. 1983. The acquired immunodeficiency syndrome and Mycobacterium avium-intracellulare bacteremia in a patient with hemophilia. Ann. Intern. Med. 98:290-293.

15. Davis, K. C., C. R. Horsburgh, U. Hasiba, A. L. Schocket, and C. H. Kirkpatrick. 1983. Acquired immunodeficiency syndrome in a patient with hemophilia. Ann. Intern. Med. 98:284-286.

16. Amman, A. J., D. W. Wara, S. Dritz, M. J. Cowan, P. Weintrub, H. Goldman, and H. A. Perkins. 1983. Acquired immunodeficiency in an infant: possible transmission by means of blood products. Lancet. I:956-958.

17. Andreani, T., Y. leCharpentier, J.-C. Brouet, J.-R. Lachance, R. Modigliani, A. Galian, M. Liance, B. Messing, and B. Vernisse. 1983. Acquired immunodeficiency with intestinal cryptosporidiosis: possible transmission by Haitian whole blood. Lancet. I:1187-1191.

18. Centers for Disease Control. 1982. Unexplained immunodeficiency and opportunistic infections in infants-New York, New Jersey and California. Morbidity and Mortality Weekly Report. 31:665-667.

19. Oleske, J., A. Minnefor, R. Cooper, K. Thomas, A. delaCruz, H. Ahdieh, I. Guerrero, V. V. Joshi, and F. Desposito. 1983. Immune deficiency syndrome in children. J. Am. Med. Assoc. 249:2345-2349.

20. Rubinstein, A., M. Sicklick, A. Gupta, L. Bernstein, N. Klein, E. Rubinstein, I. Spigland, L. Fruchter, N. Litman, H. Lee, and M. Hollander. 1983. Acquired immunodeficiency with reversed T4/T8 ratios in infants born to promiscuous and drug-addicted mothers. J. Am. Med. Assoc. 249:2350-2356.
21. Groopman, J. E., and M. S. Gottlieb. 1982. Kaposi's sarcoma: an oncologic looking glass. Nature (Lond.). 299:103-104.

22. Essex, M., M. F. McLane, T. H. Lee, L. Falk, C. W. S. Howe, J. I. Mullins, C. Cabradilla, and D. P. Francis. 1983. Antibodies to cell membrane antigens associated with human $\mathrm{T}$ cell leukemia virus in patients with AIDS. Science (Wash. DC). 220:859-862.

23. Gelmann, E. P., M. Popovic, D. Blayney, H. Masur, G. Sidhu, R. E. Stahl, and R. C. Gallo. 1983. Proviral DNA or a retrovirus, human T-cell leukemia virus, in two patients with AIDS. Science (Wash. DC). 220:862-865.

24. Gallo, R. C., P. S. Sarin, E. P. Gelmann, M. Robert-Guroff, E. Richardson, V. S. Kalyanaraman, D. Mann, G. D. Sidhu, R. E. Stahl, S. Zolla-Pazner, J. Leibowitch, and M. Popovic. 1983. Isolation of human $\mathrm{T}$-cell leukemia virus in acquired immune deficiency syndrome (AIDS). Science (Wash. DC). 220:865-867.

25. Barre-Sinoussi, F., J. C. Chermann, F. Rey, M. T. Nugeyre, S. Chamaret, J. Gruest, C. Dauguet, C. Axler-Blin, F. Vesinet-Brun, C. Rouzioux, W. Rozenbaum, and L. Montagnier. 1983. Isolation of a T-lymphotrophic retrovirus from a patient at risk for acquired immune deficiency syndrome (AIDS). Science (Wash. DC). 220:868-871.

26. Shearer, G. M. 1983. Allogeneic leukocytes as a possible factor in induction of AIDS in homosexual men. N. Engl. J. Med. 308:223.

27. Shearer, G. M., and R. B. Levy. 1983. Graft-versus-host associated immune suppression is activated by recognition of allogeneic murine I-A antigens. J. Exp. Med. 157:936-946.

28. Sonnabend, J., S. S. Witkin, and D. T. Purtilo. 1983. Acquired immune deficiency syndrome, opportunistic infections, and malignancies in male homosexuals. J. Am. Med. Assoc. 249:2370-2374.

29. Levy, J. A., and J. L. Ziegler. 1983. Acquired immunodeficiency syndrome is an opportunistic infection and Kaposi's sarcoma results from secondary immune stimulation. Lancet. I:78-81.

30. Kornfeld, H., R. A. Vande Stouwe, M. Lange, M. M. Reedy, and M. H. Grieco. 1982. T-lymphocyte subpopulations in homosexual men. N. Engl. J. Med. 307:729-731.

31. Fahey, J. L., R. Detels, and M. Gottlieb. 1983. Immune-cell augmentation (with altered $\mathrm{T}$ subset ratio) is common in healthy homosexual men. $N$. Engl. J. Med. 308:842-843.

32. Pinching, A. J., D. J. Jeffries, M. Donaghy, P. E. Munday, T. J. McManus, O. Moshtael, J. M. Parkin, J. R. W. Harris. 1983. Studies of cellular immunity in male homosexuals in London. Lancet. I: $126-130$.

33. Lederman, M. M., O. D. Ratnoff, J. J. Scillian, P. K. Jones, and B. Schacter. 1983. Impaired cell-mediated immunity in patients with classic hemophilia. N. Engl. J. Med. 308:79-83.

34. Menitove, J. E., R. H. Aster, J. T. Casper, S. J. Lauer, J. K. Gottschall, J. E. Williams, J. C. Gill, D. V. Wheeler, V. Piaskowski, P. Kirchner, and R. R. Montgomery. 1983. T-lymphocyte subpopulations in patients with classic hemophilia treated with cryoprecipitate and lyophilized concentrates. N. Engl. J. Med. 308:83-88.

35. Biddison, W. E., S. Shaw, and D. L. Nelson. 1979. Virus specificity of human influenza virus-immune cytotoxic T cells. J. Immunol. 122:660-664.

36. Shaw, S., and W. E. Biddison. 1979. HLA-linked genetic control of the specificity of human cytotoxic $\mathrm{T}$ cell responses to influenza virus. J. Exp. Med. 149:565-575.

37. Biddison, W. E. 1982. The role of the human major histocompatibility complex in cytotoxic $T$ cell responses to virus-infected cells. J. Clin. Immunol. 2:1-10. 
38. Biddison, W. E., S. M. Payne, G. M. Shearer, and S. Shaw. 1980. Human cytotoxic $\mathrm{T}$ cell responses to trinitrophenyl hapten and influenza virus. Diversity of restriction antigens and specificity of HLA-linked regulation. J. Exp. Med. 152(2, Pt. 2):204s-217s.

39. Biddison, W. E., S. O. Sharrow, and G. M. Shearer. 1981. T cell subpopulations required for the human cytotoxic and lymphocyte responses to influenza virus: evidence for $\mathrm{T}$ cell help. J. Immunol. 127:487-491.

40. Weller, T. H., and A. H. Coons. 1954. Fluorescent antibody studies with agents of varicella and herpes zoster prepared in vitro. Proc. Soc. Exp. Biol. Med. 86:789-794.

41. Henll, W., G. Henll, and C. A. Horowitz. 1974. Epstein-Barr virus specific diagnostic tests in infectious mononucleosis. Human Pathol. 5:551-565.

42. Yarchroan, R., B. R. Murphy, W. Strober, H. S. Schneider, and D. L. Nelson. 1981. Specific anti-influenza virus antibody production in vitro by human peripheral blood mononuclear cells. J. Immunol. 127:588-589.

43. Detels, R., J. L. Fahey, K. Schwartz, R. S. Greene, B. R. Vissher, and M. S. Gottlieb. 1982. The relationship between sexual practices and T-cell subset in homosexually active males. Lancet. I:609-611.

44. Lane, H. C., H. Masur, L. C. Edgar, G. Whalen, A. H. Rook, and A. S. Fauci. 1983. Abnormalities of B-cell activation and immune regulation in patients with the acquired immune deficiency syndrome. N. Engl. J. Med. 309:453-458.

45. Jaffe, H. W., K. Choi, P. A. Thomas, H. W. Haverkos, D. M. Auerbach, M. E. Guinan, M. F. Rogers, T. J. Spira, W. W. Darrow, M. A. Kramer, S. M. Friedman, J. M. Munroe, A. E. Friedman-Kien, L. J. Laubenstein, M. Marmor, B. Safai, S. K. Dritz, S. J. Crispi, S. L. Fannin, J. P. Orkwis, A. Kelter, W. R. Rushing, S. B. Thacker, and J. W. Curran. 1983. National case-control study of Kaposi's sarcoma and Pneumocystis carinii pneumonia in homosexual men: part 1, epidemiologic results. Ann. Intern. Med. 99:145-151. 